\title{
RELIEF OF CZECHIA: QUANTITATIVE EVALUATION IN THE GIS ENVIRONMENT
}

\begin{abstract}
DEMEK, J., BALATKA, B., KIRCHNER, K., MACKOVČIN, P., PÁNEK, T., SLAVÍK, P. (2011): Relief of Czechia: quantitative evaluation in the GIS environment. Geografie, 116, No. 2, pp. 111-129. - The authors used a new GIS-based geomorphological map of Czechia in the scale of 1:500,000 (Demek, Balatka, Kirchner, Mackovčin, Pánek, Slavík 2009) for computer aided quantitative evaluation of the relief of the country. The analysis showed that erosion landforms prevail in Czechia (77.14\% of the Czech territory). Summit and piedmont planation surfaces (etchplain, rock pediments, and cryopediments) that take $8.87 \%$ of the Czech territory were quantitatively evaluated over the whole Czech territory for the first time. The most common accumulation landforms were loess surfaces $(8.04 \%)$ and fluvial landforms like floodplains and accumulation river terraces (8.20\% of state territory). Polygon layer of the new GIS-based map enabled the evaluation of the geomorphodiversity of the Czech territory.

KEY WORDS: Digital geomorphological maps - computer aided methods - Czechia - geomorphodiversity.

The research was carried out by The Silva Tarouca Research Institute for Landscape and Ornamental Gardening, public research institute and funded by the Research programme MSM 6293359101 "Research into sources and indicators of biodiversity in cultural landscape in the context of its fragmentation dynamics". The research realized by the Institute of Geonics, Academy of Science of the Czech Republic, public research institute was funded by Research Project No. AVOZ 30860518.
\end{abstract}

\section{Introduction}

In the last couple of years the application of GIS technologies has provided geomorphological research with a series of new possibilities for quantitative landform analysis and construction of geomorphological databases (Dikau 1992; Gustavsson, Seijmonsbergen, Kolstrup 2008; Kertész, Markus 1992; Minár, Evans 2008; Vitek, Giardino, Fitzgerald 1996; Voženílek et al. 2001). The first and the last general geomorphological map of Czechia in the scale 1:500,000 was published 45 years ago (Stehlík, ed. 1965). The application of GIS technologies has become an important tool for data management and numerical data analysis for purposes of geomorphological research (see Hengl, Hannes, eds. 2009) from that time. The authors compiled the first GIS-based general geomorphological map of the Czech Republic in the scale 1:500,000 (Demek, Balatka, Kirchner, Mackovčin, Pánek, Slavík 2009) for the new Landscape Atlas of the Czech Republic (Hrnčiarová, Mackovčin, Zvara et al. 2009) during years 2007-2009. Geomorphological mapping run in the scale 
of 1:200,000 resulting in the final atlas map in the scale 1:500,000. A general geomorphological map forms the strongest scientific source of information and the best explanatory presentation of landforms and relief development. Obtained information was digitized in the GIS environment using products of the ESRI Company (especially ArcGIS 9.2) in the Department of GIS Application of The Silva Tarouca Research Institute for Landscape and Ornamental Gardening, public research institute in Průhonice, branch Brno (Czechia) and in ESPRIT Company in the town of Banská Štiavnica (Slovakia). This GIS-based map enabled the authors quantitatively evaluate the relief of Czechia and the geomorphodiversity of the Czech territory.

\section{Methods}

Methods used to produce the new GIS-based geomorphological map of Czechia (Demek, Balatka, Kirchner, Mackovčin, Pánek, Slavík 2009) included a combination of both topographic and thematic map interpretation, use of aerial and satellite photographs, field mapping of some geomorphological features, the use of previously published geomorphological surveys and digital data handling. Principles of the IGU Commission on Geomorphological Mapping published in the Project of the unified key to the detailed geomorphological map of the World (Bashenina et al. 1968; Demek, ed. 1972; Demek, Embleton, Kugler, eds. 1982) were used for compilation of the key. Basic mapping unit represents a discrete landform, i.e. a discrete morphologic feature that is a functionally interrelated part of the land surface formed by a specific geomorphological process or set of processes (Hengl, Hannes, eds. 2009). Shapes and locations of landforms are shown by contour lines and spot-heights. In addition to the contour lines information on slope gradients is given. Slopes were divided according to their inclination into three gradient categories $2-5$, $5-15,15$ and more degrees and expressed by various colour intensities (hue). The GIS handled all geomorphological data as separate objects. Thus, all attributes and distances among them are easily measurable. Landforms were further divided according to their origin into genetic groups in agreement with the above mentioned principles of the IGU Commission (Fig. 2). Geomorphological mapping symbols were partly developed specifically for this project and the authors partly used the digital symbol library of Létal, Voženílek (2002) and collected in the symbol library as part of the ArcGIS 9.2 extension that was used to produce the map in GIS environment. Using digital image processing techniques, different information layers were developed. Thus, landforms are in the map in three layers - polygon, point symbol and line symbol layer. The base of the map forms polygon layer. Polygon is a multi-sided figure representing an area on the map (Burrough, Rachael 1998, p. 304). The polygon layer is a map layer that displays polygon based spatial elements (landforms) that are mapped at scale. Landforms too small to be included at scale, but important from the point of view of relief genesis and processes, are presented by symbols in the point and linear layers. Each polygon, line or point is than linked to data tables that present additional data on the specific landform (see Table 1). GIS software was used for the comparative spatial and quantitative analysis of these information layers. Process/genesis is indicated by colours because 
Table 1 - Quantitative evaluation of landforms showed on the map Geomorphological conditions in the Landscape Atlas of the Czech Republic (2009)

\section{Erosion Landforms}

\begin{tabular}{|c|c|c|c|c|c|c|}
\hline No & Code & Name of landform & $\begin{array}{l}\text { Number of } \\
\text { landforms }\end{array}$ & $\begin{array}{l}\text { Min.- } \max . \\
\text { area in } \mathrm{km}^{2}\end{array}$ & $\begin{array}{r}\text { Total area } \\
\text { in } \mathrm{km}^{2}\end{array}$ & $\begin{array}{r}\text { Percent } \\
\text { of the } \\
\text { territory }\end{array}$ \\
\hline 1 & $\begin{array}{l}\text { A28 } \\
\text { A09 }\end{array}$ & Erosion slope (inclination $5-15^{\circ}$ ) & 972 & $0.2-7,301.9$ & $20,473.6$ & 25.82 \\
\hline 2 & $\begin{array}{l}\text { A28a } \\
\text { A08 }\end{array}$ & Erosion slope (inclination $2-5^{\circ}$ ) & 500 & $0.3-4,519.3$ & $18,309.6$ & 23.08 \\
\hline 3 & A29 & Erosion slope (inclination more than $15^{\circ}$ ) & 981 & $0.3-840.7$ & $9,268.6$ & 11.72 \\
\hline 4 & $\mathrm{~A} 14$ & Etchplain (inclination $0-2^{\circ}$ ) & 1,056 & $0.3-130.3$ & $3,076.2$ & 3.88 \\
\hline 5 & A14a & $\begin{array}{l}\text { Summit planation surface (in the } \\
\text { Carpathians) }\end{array}$ & 6 & $0.3-1.3$ & 4.7 & 0.01 \\
\hline 6 & A15 & Rock pediment & 483 & $0.1-112.1$ & $1,859.7$ & 2.36 \\
\hline 7 & A16 & Glacis d'érosion & 43 & $0.7-109.9$ & 415.2 & 0.53 \\
\hline 8 & A51 & Cryopediment plane & 121 & $0.7-300.8$ & $2,071.0$ & 2.63 \\
\hline 9 & A53 & $\begin{array}{l}\text { Cryoplanation terrace, cryoplanation } \\
\text { summit flat }\end{array}$ & 5 & $1.1-2.2$ & 8.9 & 0.01 \\
\hline 10 & A52 & Cryopediment back scarp & 21 & $0.5-20.5$ & 72.3 & 0.09 \\
\hline 11 & A17 & Structural plane & 340 & $0.3-576.1$ & $3,443.0$ & 4.35 \\
\hline 12 & $\begin{array}{l}\text { A23 } \\
\text { L23 }\end{array}$ & Structural scarp & $\begin{array}{r}84 \\
157 \\
\end{array}$ & $0.3-19.0$ & 312.8 & 0.40 \\
\hline 13 & A19 & Monadnock & 1,357 & $0.2-9.1$ & 671.0 & 0.85 \\
\hline 14 & $\begin{array}{l}\text { A24 } \\
\text { L24 }\end{array}$ & Mesa & $\begin{array}{r}41 \\
583 \\
\end{array}$ & $0.3-5.3$ & 201.5 & 0.26 \\
\hline 15 & $\begin{array}{l}\mathrm{A} 21 \\
\mathrm{~L} 21\end{array}$ & Cuesta escarpment & $\begin{array}{r}39 \\
101 \\
\end{array}$ & $0.3-7.7$ & 72.2 & 0.09 \\
\hline 16 & A22 & Cuesta back slope & 32 & $1.1-140.3$ & 588.4 & 0.75 \\
\hline 17 & $\begin{array}{l}\text { A18 } \\
\text { L18 }\end{array}$ & Structural range & $\begin{array}{l}478 \\
626\end{array}$ & $0.3-53.4$ & $1,317.3$ & 1.67 \\
\hline 18 & $\begin{array}{l}\text { A20 } \\
\text { L20 }\end{array}$ & Structural ridge (crest) & $\begin{array}{r}6 \\
34 \\
\end{array}$ & $0.4-2.4$ & 6.5 & 0.01 \\
\hline 19 & A25 & Klippe & 7 & $0.2-1.2$ & 3.9 & 0.00 \\
\hline 20 & A26 & Mendip & 17 & $0.3-2.3$ & 14.8 & 0.02 \\
\hline 21 & $\begin{array}{l}\text { A27 } \\
\text { B27 }\end{array}$ & Exfoliation dome, ruware, bornhardt & $\begin{array}{l}12 \\
47\end{array}$ & $0.3-2.6$ & 8.0 & 0.01 \\
\hline 22 & $\begin{array}{l}\text { A43 } \\
\text { B43 }\end{array}$ & Pseudokarst rock city & $\begin{array}{l}16 \\
21\end{array}$ & $0.7-111.9$ & 302.7 & 0.38 \\
\hline 23 & A47 & Karst canyon, gorge & 2 & $1.0-16.5$ & 17.5 & 0.02 \\
\hline 24 & $\begin{array}{l}\text { A48 } \\
\text { B48 }\end{array}$ & Landslide, group of landslides & $\begin{array}{r}12 \\
856 \\
\end{array}$ & $0.9-3.5$ & 17.0 & 0.02 \\
\hline 25 & A69 & Erosion surface on ground moraine & 30 & $1.0-20.4$ & 136.7 & 0.17 \\
\hline 26 & $\begin{array}{l}\text { A57 } \\
\text { B57 }\end{array}$ & Nivation hollow & $\begin{array}{r}1 \\
67\end{array}$ & $0.6-0.6$ & 0.6 & 0.00 \\
\hline 27 & A61 & Roche moutonnée & 6 & $0.1-2.7$ & 5.0 & 0.01 \\
\hline 28 & B58 & $\begin{array}{l}\text { Cirque of Pleistocene glacier with } \\
\text { moraine }\end{array}$ & 15 & - & - & - \\
\hline 29 & B30 & Meander core & 19 & - & - & - \\
\hline 30 & B35 & Karst doline & 4 & - & - & - \\
\hline 31 & B36 & Abyss & 3 & - & - & - \\
\hline 32 & B55 & Tor, castle koppie & 734 & - & - & - \\
\hline
\end{tabular}




\begin{tabular}{|lllrrrr|}
\hline No & Code & Name of landform & $\begin{array}{r}\text { Number of } \\
\text { landforms }\end{array}$ & $\begin{array}{r}\text { Min.-max. } \\
\text { area in } \mathrm{km}^{2}\end{array}$ & $\begin{array}{r}\text { Total area } \\
\text { in } \mathrm{km}^{2}\end{array}$ & $\begin{array}{r}\text { Percent } \\
\text { of the } \\
\text { territory }\end{array}$ \\
\hline 33 & B41 & Mogote & 2 & - & - \\
\hline 34 & L33 & Gully & 1,528 & - & - \\
\hline 35 & L56 & Dell & 368 & - & - \\
\hline & Total & & & & - \\
\hline
\end{tabular}

\section{Accumulation Landforms}

\begin{tabular}{|c|c|c|c|c|c|c|}
\hline 36 & A74 & Surface of loess & 361 & $0.4-331.6$ & $6,370.3$ & 8.04 \\
\hline 37 & A65 & Floodplain & 124 & $0.3-1,675.6$ & $3,791.0$ & 4.79 \\
\hline 38 & A64b & $\begin{array}{l}\text { River accumulation terrace Middle } \\
\text { Pleistocene }\end{array}$ & 357 & $0.3-37.8$ & $1,291.1$ & 1.64 \\
\hline 39 & $\mathrm{~A} 64 \mathrm{c}$ & $\begin{array}{l}\text { River accumulation terrace Lower } \\
\text { Pleistocene }\end{array}$ & 192 & $0.2-58.9$ & 650.4 & 0.82 \\
\hline 40 & $\mathrm{~A} 64 \mathrm{a}$ & $\begin{array}{l}\text { River accumulation terrace Upper } \\
\text { Pleistocene }\end{array}$ & 85 & $0.3-82.7$ & 533.0 & 0.68 \\
\hline 41 & A72 & Surface of aeolian sands & 47 & $0.5-140.1$ & 470.4 & 0.60 \\
\hline 42 & A71 & Outwash plain, sandur & 51 & $0.4-107.7$ & 469.7 & 0.60 \\
\hline 43 & A62 & Proluvial plain & 35 & $0.5-61.8$ & 340.0 & 0.43 \\
\hline 44 & A75 & Surface of peat bogs & 87 & $0.3-22.4$ & 240.2 & 0.30 \\
\hline 45 & $\mathrm{~A} 63$ & Alluvial (proluvial) cone & 73 & $0.3-2.8$ & 181.7 & 0.23 \\
\hline 46 & $\mathrm{~A} 64$ & River accumulation terrace (unclassified) & 64 & $0.3-18.6$ & 154.9 & 0.20 \\
\hline 47 & A66 & Debris slope & 44 & $0.4-28.4$ & 132.2 & 0.17 \\
\hline 48 & A64d & River accumulation terrace, Neogene & 30 & $0.3-15.6$ & 59.1 & 0.07 \\
\hline 49 & $\begin{array}{l}\text { A73 } \\
\text { B73 }\end{array}$ & Sand dune & $\begin{array}{r}17 \\
121 \\
\end{array}$ & $0.4-1.3$ & 10.7 & 0.01 \\
\hline 50 & $\begin{array}{l}\mathrm{A} 68 \\
\mathrm{~L} 68 \\
\end{array}$ & Block stream, mud flow & $\begin{array}{l}1 \\
2\end{array}$ & $0.6-0.6$ & 0.6 & 0.00 \\
\hline 51 & B67 & Block field, felsenmeer & 921 & - & - & - \\
\hline 52 & L76 & Organic deposits in oxbow & 67 & - & - & - \\
\hline & Total & & & & & 18.58 \\
\hline
\end{tabular}

\section{Neotectonic Landforms}

\begin{tabular}{|lllrrrr|}
\hline 53 & A01 & Fault scarp & 541 & $0.3-19.0$ & 907.3 & 1.15 \\
\hline 54 & A06 & Slope of anticline & 3 & $15.8-42.4$ & 90.4 & 0.11 \\
\hline 55 & A07 & Slope of syncline & 1 & $30.1-30.1$ & 30.1 & 0.04 \\
\hline 56 & L02 & Axis of megaanticline & 21 & - & - & - \\
\hline 57 & L03 & Axis of megasyncline & 7 & - & - & - \\
\hline 58 & L04 & Axis of anticline & 15 & - & - \\
\hline 59 & L05 & Axis of syncline & 12 & - & - & - \\
\hline & Total & & & & & 1.30 \\
\hline
\end{tabular}

\section{Neovolcanic Landforms}

\begin{tabular}{|lllrrrr|}
\hline 60 & A10 & Neovolcanic knob and cone & 219 & $0.1-16.0$ & 102.0 & 0.13 \\
\hline 61 & A11 & Exudates subvolcanic body & 364 & $0.1-1.9$ & 93.5 & 0.12 \\
\hline 62 & A12 & Exposed vein, wall & 2 & $0.3-0.3$ & 0.6 & 0.00 \\
\hline & Total & & & & 0.25 \\
\hline
\end{tabular}


5. Man-made Landforms

\begin{tabular}{|c|c|c|c|c|c|c|}
\hline No & Code & Name of landform & $\begin{array}{l}\text { Number of } \\
\text { landforms }\end{array}$ & $\begin{array}{l}\text { Min.-max. } \\
\text { area in } \mathrm{km}^{2}\end{array}$ & $\begin{array}{r}\text { Total area } \\
\text { in } \mathrm{km}^{2}\end{array}$ & $\begin{array}{r}\text { Percent } \\
\text { of the } \\
\text { territory }\end{array}$ \\
\hline 63 & $\begin{array}{l}\text { A77a } \\
\text { B77a }\end{array}$ & Stone quarry active & $\begin{array}{r}7 \\
321 \\
\end{array}$ & $0.4-4.25$ & 11.4 & 0.01 \\
\hline 64 & B77n & Stone quarry non-active & 1,324 & - & - & - \\
\hline 65 & $\begin{array}{l}\mathrm{A} 78 \mathrm{a} \\
\mathrm{B} 78 \mathrm{a}\end{array}$ & Gravel pit, sand pit active & $\begin{array}{r}22 \\
108 \\
\end{array}$ & $0.6-10.7$ & 49.7 & 0.06 \\
\hline 66 & $\begin{array}{l}\text { A78n } \\
\text { B78n }\end{array}$ & Gravel pit, sand pit non-active & $\begin{array}{r}16 \\
294 \\
\end{array}$ & $0.7-4.9$ & 27.7 & 0.04 \\
\hline 67 & $\begin{array}{l}\text { A79 } \\
\text { B79 }\end{array}$ & Mine dump, setting pit & $\begin{array}{r}129 \\
47\end{array}$ & $0.2-74.7$ & 389.0 & 0.49 \\
\hline 68 & $\mathrm{~B} 79 \mathrm{a}$ & Mine adit, winding shaft active & 15 & - & - & - \\
\hline 69 & B79n & Mine adit, winding shaft non-active & 149 & - & - & - \\
\hline 70 & $\mathrm{~B} 80$ & Collapse sink, group of collapse sink & 3 & - & - & - \\
\hline 71 & $\mathrm{~A} 81$ & Mining subsidence depression & 2 & $0.7-3.0$ & 3.6 & 0.00 \\
\hline 72 & A82 & Loam pit, clay pit & 310 & $1.5-2.4$ & 9.1 & 0.01 \\
\hline 73 & $\mathrm{~A} 83$ & Open-cast mine & 11 & $0.3-29.9$ & 97.8 & 0.12 \\
\hline & Total & & & & & 0.73 \\
\hline
\end{tabular}

Explanation: A - polygonal layer, L - linear symbol layer, B - point symbol layer, - data from linear (L) and point (B) symbol layer, areal data not available

colour is the most eye-catching graphic variable. The age of landforms is given in letter code. During compilation of the final atlas map was required certain generalization of landforms according to their spatial extent and importance (e.g. monadnocks and mesas). Processing of the map in the GIS environment enabled to obtain new quantitative information on geomorphodiversity.

\section{Relief of Czechia: basic quantitative data}

\subsection{Quantitative evaluation of erosion landforms}

Erosion landforms are predominating on the territory of Czechia according to the quantitative relief evaluation in the GIS environment (see Tab. 1 and Fig. 3). The most common landforms are fluvial erosion slopes present over an area of $48,051.8 \mathrm{~km}^{2}$ (63.62\% of the Czech territory). Gentle fluvial erosion slopes inclined $2-5^{\circ}$ (totalling 500 patches) take $18,309.6 \mathrm{~km}^{2}(23.08 \%$ of the state territory). Patches in this group have mean area of $42.2 \mathrm{~km}^{2}$. The most common landforms are fluvial moderate slopes inclined $5-15^{\circ}$ (totalling 972 patches) that cover an area of $20,473.6 \mathrm{~km}^{2}$ (25.82\% of the Czech territory). Patches in this group are of the average area of $21.6 \mathrm{~km}^{2}$. Steep slopes inclined more than $15^{\circ}$ (981 patches) take $9,268.6 \mathrm{~km}^{2}$ (11.72\% of the country). Patches in this group are of the average area of $9.4 \mathrm{~km}^{2}$.

Apart from erosion slopes, structural slopes are also common controlled by exposures of resistant bedrock. The map contains 241 localities of structural scarps in total $632.3 \mathrm{~km}$ long and spreading over an area of $312.8 \mathrm{~km}^{2}(0.40 \%$ of the Czech territory). 
Flat horizontal or gentle inclined (from 0.1 to $2^{\circ}$ ) erosion relief is present in the form of either polygenetic planation surfaces or structural flats. The summit polygenetic planation surfaces are represented by etchplain flats cutting old bedrock of the Bohemian Massif and the Moravian-Silesian terrane. The authors delimited 1,056 flats with the extent of more than 30 hectares (the larges flat has the extent of $130.3 \mathrm{~km}^{2}$ ). Etchplain covers the area of $3,076.2 \mathrm{~km}^{2}$ (3.88\% of the Czech territory). Above a gently rolling etchplain conspicuously rise many monadnocks. Due to the high number of monadnocks a restriction of the smaller monadnocks was carried out by a computer and leaving 1,357 monadnocks with areas greater than 40 hectares only.

In the Carpathian's part of Czechia the top summit planation surface developed in the Javorníky Mts., where 6 flats on summits and mountain ridges larger than 30 hectares are present on the area of $4.7 \mathrm{~km}^{2}$. Summit flats earlier interpreted by Czech geomorphologists as summit planation surfaces are now mostly shown in the map as structural surfaces controlled by subhorizontaly bedded sandstones.

An area of low relief developed upon gently tilted or horizontally bedded Cretaceous sedimentary rocks of the Bohemian Plateau especially in North Bohemia. Less resistant layers have been removed by erosion thereby revealing a more resistant stratum (e.g. quartzose block sandstones) forming structural plateaus. The map shows 340 structural planes that taking the area of $3,443.0 \mathrm{~km}^{2}$ (4.37\% of the Czech territory). Above flat structural relief rise on many localities isolated flat-topped hills (mesas) of different parameters. Due to the scale of the map a computer study was carried out leaving the authors with 624 mesas on the map (41 mesas greater than 30 hectares in the polygon layer and 583 mesas in the point layer). Mesas take the area of $201.5 \mathrm{~km}^{2}$ ( $0.26 \%$ of the country).

Distribution of piedmont planation surfaces - rock pediments and glacis d'érosion, is shown on the map for the first time for the whole state territory. The authors delimited 483 rock pediments with a total area of $1,859.7 \mathrm{~km}^{2}$ (2.36\% of the Czech territory). On some localities rock pediments developed in two levels coalescing into a pediplain. Valley rock pediments originated by the recession of the scarp above are common in the Czech Republic. Rarer are glacis d'érosion developed by the migrating stream channels on less resistant rocks at the foot of slopes composed of more resistant rocks. The map shows 43 glacis d'érosion with the area of $415.2 \mathrm{~km}^{2}(0.53 \%$ of the Czech territory). Cryopediments are piedmont planation surfaces developed in cold periods of the Pleistocene Epoch in permafrost conditions. The map shows 121 cryopediments of larger extent (see Table 1) that in polygon layer cover the area of $2,071.0 \mathrm{~km}^{2}$ (2.63\% of the Czech territory). There are also 21 localities of higher cryopediment backslopes represented on the map. These data show that piedmont planation surfaces represent an important part of the land-surface of Czechia. The authors incorporated also cryoplanation terraces and cryoplanation summit flats among planation surfaces. This general map shows only 5 localities of large cryoplanation terraces and cryoplanation summit flats in the Mts. Hrubý Jeseník and the Rychlebské hory Mts. covering the total of $8.9 \mathrm{~km}^{2}$.

Structural denudation ranges developed in gently dipping strata. These landforms cover the area of $1,317.3 \mathrm{~km}^{2}$ (1.67\% of the Czech territory) and in 
both the polygon and linear layers are $1,184.6 \mathrm{~km}^{2}$ long. There are also 140 localities of structural ridges with an asymmetrical cross section of escarpment and back slope (cuestas) on the map. Steep cuestas escarpments that cut across the strata cover the area of $72.2 \mathrm{~km}^{2}(0.09 \%$ of Czech territory) and in both the polygon and linear layers are $376.9 \mathrm{~km}^{2}$ long. The gentle long cuestas back slopes cover the area of $588.4 \mathrm{~km}^{2}(0.75 \%$ of the Czech territory). Back slopes are partly dip slopes and partly planation surfaces.

The polygonal layer contains 6 localities of structural crests $\left(6.5 \mathrm{~km}^{2}, 0.01 \%\right.$ of the Czech territory) and linear symbol layer then 34 localities with the total lengths of crests of $51 \mathrm{~km}$.

There are 7 klippens present in the Carpathians covering the area of $3.9 \mathrm{~km}^{2}$ and 17 mendips of the area of $14.8 \mathrm{~km}^{2}$ in the Carpathian's foredeep.

Rock cities are of the largest area in the genetic group of pseudokarst erosion landforms. The polygon layer contains 16 pseudokarst rock cities in the polygon layer (the area of $302.7 \mathrm{~km}^{2}, 0.38 \%$ of the Czech territory) and the point layer shows 21 localities. Small pseudokarst landforms are represented in point layer (see Table 1). These landforms are together with landforms of polygenetic or cryogenic origin very important for the geomorphodiversity of the Czech territory (e.g. 734 tors and castle koppies in the point layer).

In conclusion to this group of landforms it is necessary to mention the 1,528 gullies and gorges 2,996.1 km long and 368 expressive dells of the total of $612.8 \mathrm{~km}$ long. The number of dells is of course much higher within the territory of Czechia than the number of dells that could be shown on the general map.

\subsection{Quantitative evaluation of accumulation la $\mathrm{ndf}$ or m s}

Surfaces on loess are the most common accumulation landform in the relief of Czechia, especially in lowlands and low plateaus (a total of $6,370.3 \mathrm{~km}^{2}$, $8.04 \%$ of the Czech territory). These surfaces mostly covered by fertile agricultural soils are commercially very important. Flat surfaces of floodplains covering an area of $3,791.0 \mathrm{~km}^{2}$ follow (4.79\% of the Czech territory). Surfaces of accumulation river terraces also represent a large areas (see Table 1), following the riverbeds of Czech rivers and covering $2,688.5 \mathrm{~km}^{2}(3.41 \%$ of the Czech territory). Proluvial plains $\left(340.0 \mathrm{~km}^{2}, 0.43 \%\right.$ of the Czech territory) and proluvial cones ( $181.7 \mathrm{~km}^{2}, 0.23 \%$ of the Czech territory) from the group of fluvial landforms follow.

In parts of the country covered by inlandsis during the Pleistocene glacial periods are the most common accumulation landforms outwash-plains (sandurs). The map shows 51 localities covering the area of $469.7 \mathrm{~km}^{2}(0.60 \%$ of the state territory).

Aeolian sands represent a smaller area, in some places with sand dunes (470.4 $\mathrm{km}^{2}, 0.60 \%$ of the Czech territory). In total 138 sand dunes covering in polygonal layer the area of $10.7 \mathrm{~km}^{2}(0.01 \%$ of the Czech territory) are presented on the map. Relatively high is the number of polygenetic and cryogenic block fields (felsenmeeres) included into the point symbol layer (921 localities in total). 


\subsection{Quantitative evaluation of neotectonic l a nd for m s}

Neotectonic landforms on the territory of Czechia are divided into two groups - block and fold landforms. From the group of block landforms are there are 541 localities of fault scarps of different heights and expressiveness shown on the map. From this number 461 fault scarps are shown in the polygonal layer and these landforms cover the total of $907.3 \mathrm{~km}^{2}(1.15 \%$ of the Czech territory), another 80 localities are shown in the linear symbol layer. The total lengths of fault scarps reach $2,501.3 \mathrm{~km}$.

From the group of fold neotectonic landforms group there are 13 localities of anticlinal slopes shown in the polygonal layer covering the area of $90.4 \mathrm{~km}^{2}$ $\left(0.11 \%\right.$ of the state territory) and 1 locality of synclinal slopes $\left(30.1 \mathrm{~km}^{2}, 0.04 \%\right.$ of the Czech territory). In the linear symbol layer there are axes of 21 megaanticlines marked (total lengths of $378.8 \mathrm{~km}$ ) and the axes of 7 megasynclines (total lengths of $342.0 \mathrm{~km}$ ). Further in this layer are shown axes of 5 anticlines of normal folds (total lengths of $282.8 \mathrm{~km}$ ) and 12 synclines (total of lengths $468.0 \mathrm{~km}$ ).

\subsection{Quantitative evaluation of neovolcanic land forms}

In the genetic group of neovolcanic landforms are traditionally included landforms originated by volcanic activity in the Tertiary and Quaternary Periods. In reality these landforms were substantially changed by erosion into erosion and exudated landforms. Nevertheless these landforms are important from the geomorphological diversity (geomorphodiversity) point of view. The authors showed 129 neovolcanic knobs and cones of the total area of $102.0 \mathrm{~km}^{2}(0.13 \%$ of the Czech territory) in the map. From the subgroup of exudated subvolcanic bodies the landforms greater than 12 hectares were marked in the map. The map shows 364 exudated subvolcanic bodies covering the area of $93.5 \mathrm{~km}^{2}$ ( $0.12 \%$ of the Czech territory). Separately are presented exudated neovolcanic vein and wall (with an area of $0.5 \mathrm{~km}^{2}, 0.01 \%$ of the Czech territory).

\subsection{Quantitative evaluation of anthropogenic land form s}

Man-made landforms are very dynamic relief feature undergoing permanently rapid changes (see Table 1). New anthropogenic landforms are constructed; old landforms are recultivated or filled up (reclaimed). The authors met problems in the mapping of the anthropogenic pressure on the relief. Maps of mineral deposits of Czechia in the scale 1:50,000 are out of date, because the situation in mineral extraction industry rapidly changed after 1989 (Smolová 2008). The authors used incomplete digital database of the Czech Geological Survey and actual aerial photographs. A lot of anthropogenic landforms were recultivated. On the other hand in places with the concentration of man-made landforms some generalization was necessary due to the scale of the map. 
The map shows 328 active stone quarries covering the area of $11.4 \mathrm{~km}^{2}$ ( $0.1 \%$ of the Czech territory). The authors delimited many more non-active stone quarries (1,324 localities), but this number keeps changing due to filling-up and recultivation. Larger pressure on the relief is made by active sand and gravel pits that cover the area of $49.7 \mathrm{~km}^{2}(0.06 \%$ of the Czech territory). The map shows 176 non-actives sand and gravel pits (area $27.7 \mathrm{~km}^{2}$, $0.04 \%$ of the Czech territory). Loam pits and clay pits are also included in the map (310 localities, area $9.1 \mathrm{~km}^{2}, 0.01 \%$ of the Czech territory). Typical man-made landforms are large open-cast mines in West Bohemia. The map shows 11 great open-cast mines covering the area of $97.8 \mathrm{~km}^{2}(0.12 \%$ of the Czech territory). Large areas are also taken by mine dumps and setting pits (total $389 \mathrm{~km}^{2}, 0.49 \%$ of the Czech territory). The point symbol layer contains further anthropogenic landforms.

\section{Quantitative evaluation of geomorphodiversity}

The authors used the polygon layer for quantitative evaluation of spatial structures of the relief in GIS environment together with quantitative evaluation of individual landforms and groups of landforms. In general spatial structures of the relief are associated with the composition and configuration of landforms. Composition refers to the number and occurrence of different

Table 2 - Elements of geodiversity (Serrano, Ruiz-Flano 2007)

\begin{tabular}{|c|c|c|}
\hline Topography & $\begin{array}{l}\text { Energy } \\
\text { Roughness }\end{array}$ & \\
\hline \multirow[t]{2}{*}{ Geology } & Earth material & $\begin{array}{l}\text { Minerals } \\
\text { Lithology (rocks) } \\
\text { Superficial deposits }\end{array}$ \\
\hline & $\begin{array}{l}\text { Tectonics } \\
\text { Structures }\end{array}$ & \\
\hline Geomorphology & $\begin{array}{l}\text { Morphostructures } \\
\text { Morphogenetic systems } \\
\text { Processes } \\
\text { Erosion landforms } \\
\text { Accumulation landforms } \\
\text { Micro-landforms }\end{array}$ & \\
\hline \multirow[t]{2}{*}{ Hydrology } & Water states & $\begin{array}{l}\text { Water } \\
\text { Snow } \\
\text { Ice } \\
\text { Glaciers }\end{array}$ \\
\hline & Hydrologic elements & $\begin{array}{l}\text { Oceans } \\
\text { Seas } \\
\text { Rivers } \\
\text { Springs } \\
\text { Wetlands } \\
\text { Lakes }\end{array}$ \\
\hline Soils & $\begin{array}{l}\text { Orders } \\
\text { Suborders }\end{array}$ & \\
\hline
\end{tabular}


types of landforms, while configuration encompasses the spatial distribution or spatial character within the relief. In this context numerous mathematical indices have been developed allowing the objective description of different aspects of relief structures and patterns (geomorphometry - Hengl, Hannes, eds. 2009) and coming to the terms of geodiversity and geomorphodiversity. Geodiversity is a rather new, emerging topic in Earth sciences (Cílek 2002; Ložek 2006; Hjort, Luoto 2010), especially in geomorphology. Elements of geodiversity see Table 2 . The relief is an important element of geodiversity (Serrano, Ruiz-Flano 2007). Geomorphodiversity is than a critical and specific assessment of geomorphological features of a territory, by comparing them in an extrinsic and in intrinsic way, taking into account the scale of investigation, the purpose of research and the level of scientific quality (Panizza 2009a, b).

An increasing attention is paid to the need to understand patterns of geomorphodiversity on different types of Earth's relief. The authors quantified the spatial variation of geomorphodiversity in Czechia using two different measures - landform density and number of genetic classes. For computing authors used a spatial grid based on geographical coordinates from the official Czech Information System of Nature Protection (DISOP). The grid contains 679 cells within the territory of Czechia. The basic cell on the 50th parallel north is represented by the area of $12 \times 11.1 \mathrm{~km}$. Therefore the average area of the grid cell is $133.5 \mathrm{~km}^{2}$. The maps are derived from the polygon layer of the atlas map Geomorphological Conditions (Demek, Balatka, Kirchner, Mackovčin, Pánek, Slavík 2009) and related geomorphological database.

\subsection{Landform Density (HPT)}

A landform represents in GIS-environment a patch which is covered by one single code number (see Table 1) in the polygon layer. Relief of Czechia is composed of a mosaic of landforms (patches). The landforms density (HPT) expresses the number of landforms (patches) within the entire reference unit (window of $12 \times 11.1 \mathrm{~km}$ ). It is calculated as

$H P T=\frac{a}{n} \quad$ (Eiden, Kayadjanian, Vidal 2010, p. 2)

where $H P T=$ Landform Density, $n=$ Number of Landforms, $a=$ reference unit (area).

Landform Density increases with a greater number of landforms within the reference area (grid cell).

In general index of landform density it depends on the "grain size" of the input data from the polygon layer, i.e. the size of the smallest landform mapped (e.g. 13 hectares in the neovolcanic group or 0.21 hectares in the case of monadnocks). The number of landforms in grid windows varies from 1 to 20 per grid cell. Topographically, the high-geomorphodiversity sites occurred in places where both natural erosion and accumulation processes and anthropogenic activities play a major role in relief development (see Fig. 2). Cells with a high landform density (from 15 to 20) are concentrated in the northwestern part of the Czech territory (the Ore Mts. and the Ohře Rift, volcanic mountains the Doupovské hory Mts. and the České středohoří Mts.). A high density of landforms is concentrated in the Bohemian Karst with karst landforms 
Table 3 - Landform Density

\begin{tabular}{|cc|lc|}
\hline $\begin{array}{l}\text { Number of land- } \\
\text { forms in a grid cell }\end{array}$ & $\begin{array}{c}\text { Frequency } \\
\text { (N - integer) }\end{array}$ & $\begin{array}{l}\text { Number of land- } \\
\text { forms in a grid cell }\end{array}$ & $\begin{array}{c}\text { Frequency } \\
\text { (N - integer) }\end{array}$ \\
\hline 1 & 3 & 11 & 60 \\
2 & 18 & 12 & 34 \\
3 & 19 & 13 & 26 \\
4 & 36 & 14 & 16 \\
5 & 64 & 15 & 6 \\
6 & 85 & 16 & 4 \\
7 & 83 & 17 & 3 \\
8 & 79 & 18 & 0 \\
9 & 83 & 19 & 1 \\
10 & 59 & 20 & 1 \\
\hline
\end{tabular}

Table 4 - Number of landform classes (total geomorphodiversity - NGC)

\begin{tabular}{|lc|}
\hline Number of landform classes in a grid cell & Frequency (units) \\
\hline 1 & 113 \\
2 & 267 \\
3 & 225 \\
4 & 63 \\
5 & 11 \\
\hline
\end{tabular}

around the deeply incised Berounka River. valley and in dissected Cretaceous plateau of Polomené hory (Protected Landscape Area Kokořínsko) with rock cities and gorges in the Central Bohemia. In the Eastern Bohemia the large density of landforms is presented in the cuesta landscape of the Jestřebí hory Mts. The most common are the cells with 5, 6, 7, 8 and 9 landforms that prevail in the central and southern part of the country (see Map 2). The index is a good reflection of the extent to which relief is fragmented and is therefore fundamental for the assessment of relief structures, enabling comparisons of units of various sizes.

\subsection{Number of genetic landform classes (total geodiversity - NGC)}

Another measure of capturing the geomorphodiversity was used to count the number of different categories, in our case genetic landform classes within a reference unit. The more classes there are the more diverse the area is. The advantage of this index is that it can be calculated and interpreted easily. However the result might be misleading, because the area covered by each class and therefore its importance is not considered. Even if a certain landform class covers only the smallest possible area (e.g. monadnock), it is counted in. The authors divided landforms into 5 classes (see Table 1 and Table 4). The cells with the largest number genetic classes (4 and 5) are again concentrated in the northwestern part of the country (the Ore Mts. and the Ohře Rift, vol- 
canic mountains of the Doupovské hory Mts. and the České středohoří Mts.). Areas with 2 and 3 landform classes prevail in Czechia (see Fig. 3).

\section{Conclusion}

The land-surface that surrounds us is essential to the life and activity of our society and the understanding of its characteristics and processes are important for sustainable development. The compilation of the new GIS-based geomorphological map (Demek, Balatka, Kirchner, Mackovčin, Pánek, Slavík 2009) enabled quantitative evaluation of the relief of the Czech Republic in Central Europe and has provided new information. The largest area in Czechia is covered by fluvial erosion slopes ( $60.56 \%$ of the Czech territory), out of which the largest area is covered by slopes inclined from 5 to $15^{\circ}(25.82 \%)$. Surfaces of the Pleistocene loess covers $\left(6,370.3 \mathrm{~km}^{2}, 8.08 \%\right.$ of the Czech territory) follow on the second place as the evidence of large wind activity in the periglacial landscapes during the cold periods of the Pleistocene. Types of planation surfaces namely polygenetic and cryogenic surfaces on the territory of Czechia were cartographically represented for the first time. Polygenetic planation surfaces are the remains of etchplain and summit planation flats in the Carpathians and are also piedmont planation surfaces (e.g. rock pediments, glacises d'erosion and cryopediments). The polygon layer of the GIS-based map enabled the evaluation of geomorphodiversity of the Czech territory. GIS is thus an important instrument of geomorphological survey. Further development in digital GIS-based geomorphological maps may lead to standardized automated terrain-analysis techniques and more insight into evolution of the Czech land surface that formed for a long time.

The authors are grateful to two anonymous reviewers for valuable comments and to Dr. Teresa M. Rusch (London) for linguistic improvement of the paper.

\section{References:}

BASHENINA, N.V. et al. (1968): Project of the unified key to the detailed geomorphological map of the World. Folia Geographica Serie geographica - physica, II, pp. 1-24.

BURROUGH, P.A., RACHAEL, A.M. (1998): Principles of geographical information systems. Oxford University Press, New York.

CÍLEK, V. (2002): Krajiny vnitřní a vnější. Dokořán, Praha, 232 pp.

DEMEK, J., ed. (1972): Manual of Detailed Geomorphological Mapping. International Geographical Union Commission on Geomorphological Survey and Mapping, Academia, Prague, $343 \mathrm{pp}$.

DEMEK, J., ed. (1976): Handbuch der geomorphologischen Detailkartierung. Hirt, Wien, $463 \mathrm{pp}$.

DEMEK, J., BALATKA, B., KIRCHNER, K., MACKOVČIN, P., PÁNEK, T., SLAVÍK, P. (2009): Geomorphological Conditions 1:500,000. In: Hrnčiarová, T., Mackovčin, P., Zvara, I. et al.: Landscape Atlas of the Czech Republic. Ministry of Environment of the Czech Republic, The Silva Tarouca Research Institute for Landscape and Ornamental Gardening, Praha.

DEMEK, J., EMBLETON, C., KUGLER, H. (1982): Geomorphologische Kartierung in mittleren Maßstäben: Grundlagen, Methoden, Anwendungen. Petermanns geographische Mitteilungen / Ergänzungsheft, 281, 254 pp. 


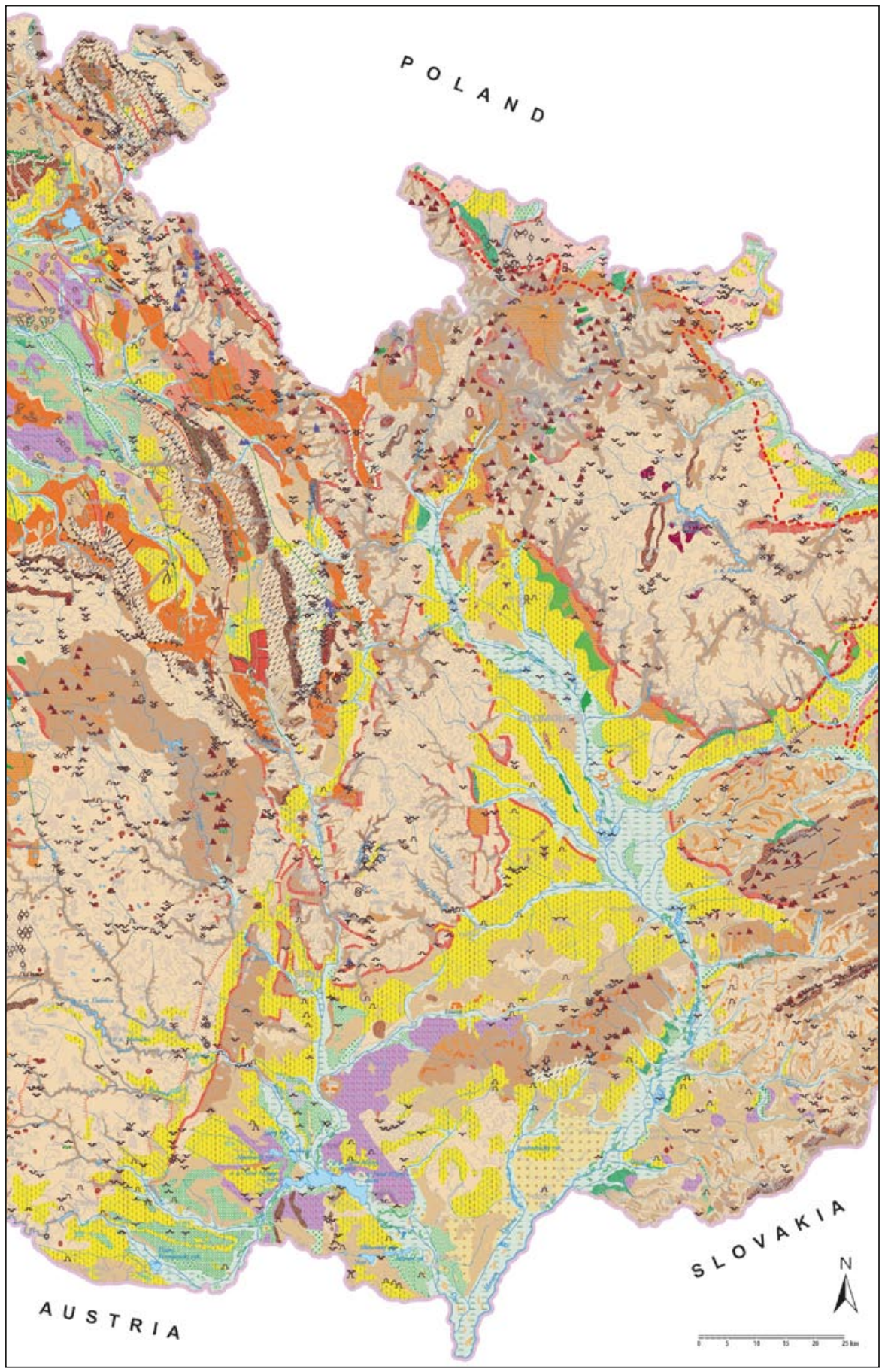

Fig. 1 - Example of the GIS-based geomorphological map of Czechia (Demek, Balatka, Kirchner, Mackovčin, Pánek, Slavík 2009) 




Fig. 2 - Legend to the GIS-based geomorphological map of Czechia (Demek, Balatka, Kirchner, Mackovčin, Pánek, Slavík 2009) 


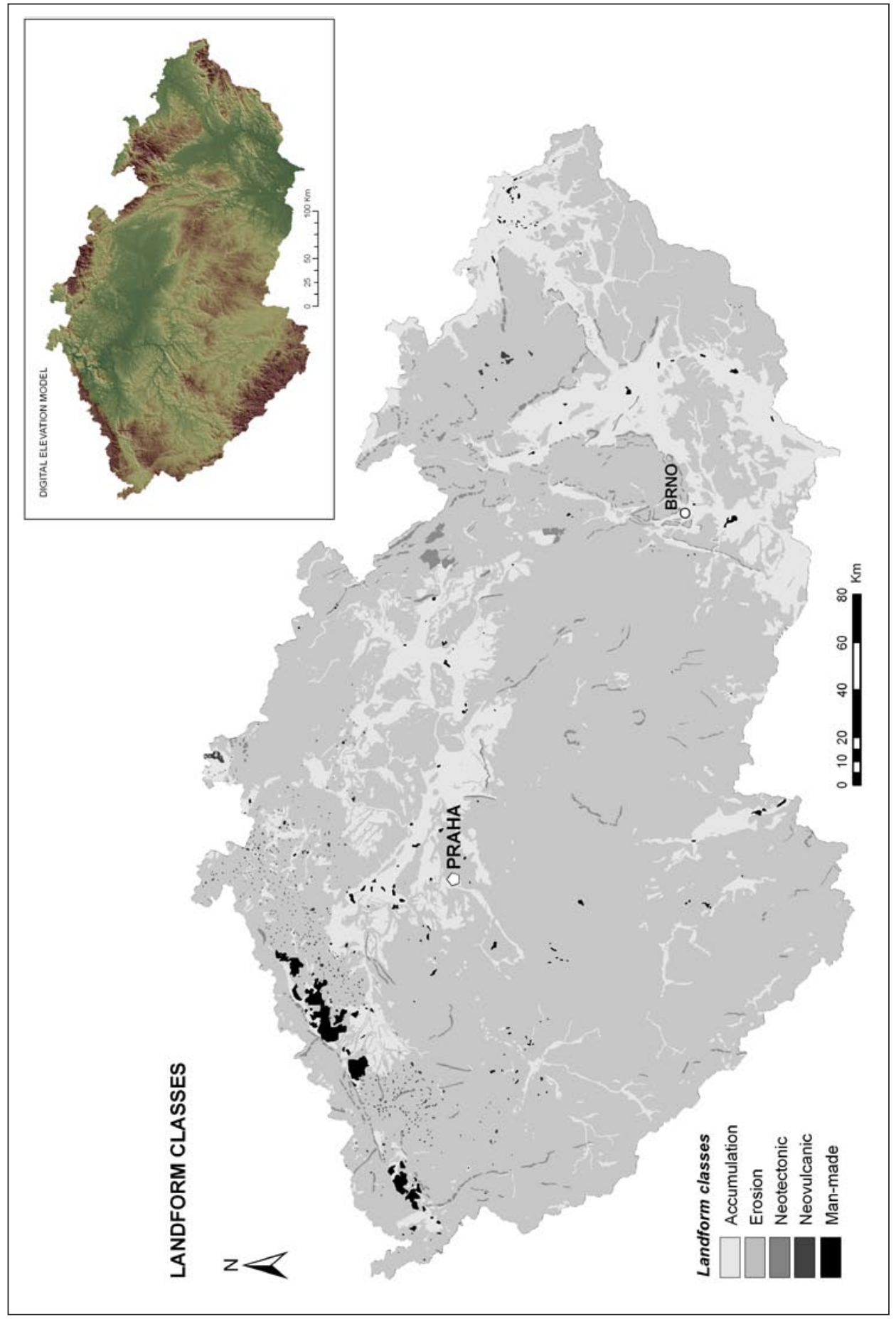

Fig. 3 - Distribution of landform classes on the territory of Czechia 


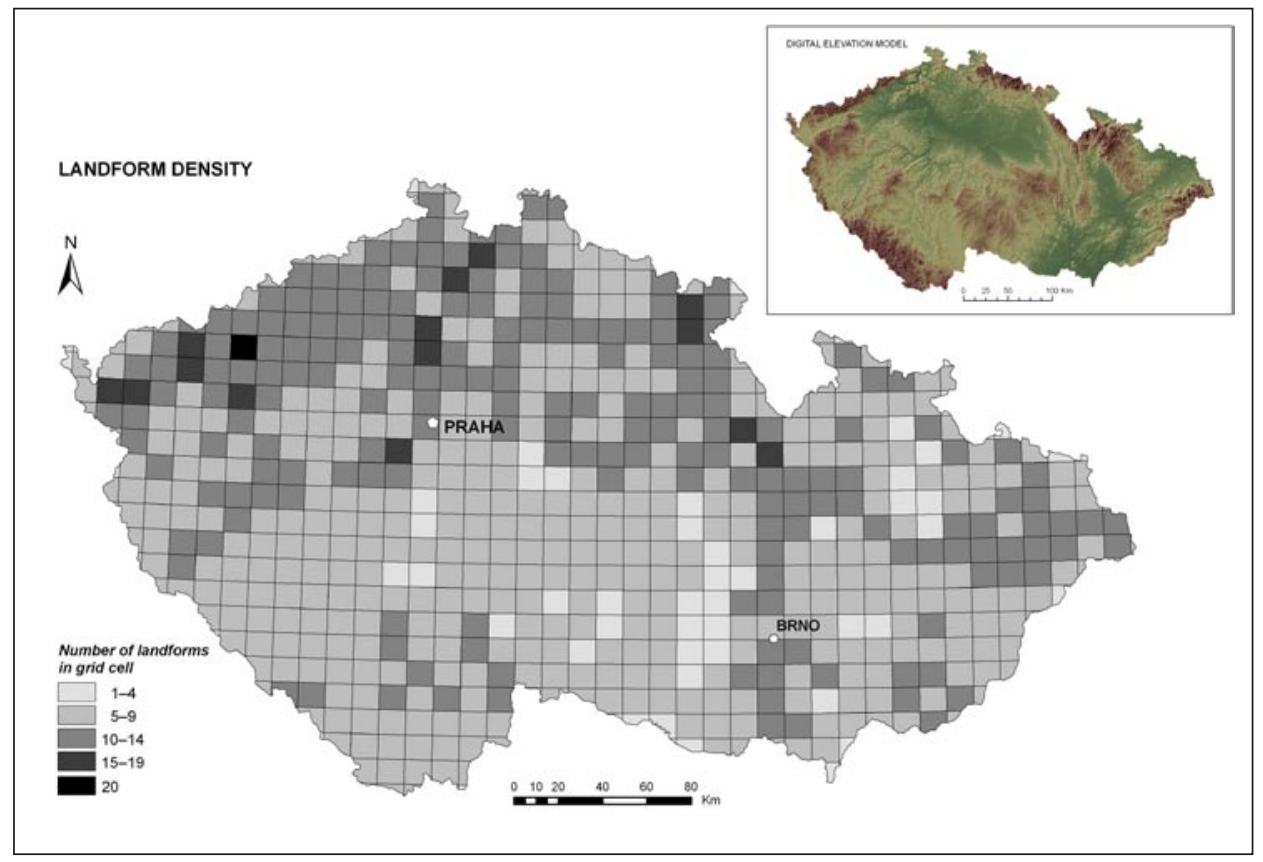

Fig. 4 - Landform density (HPT) on the territory of Czechia

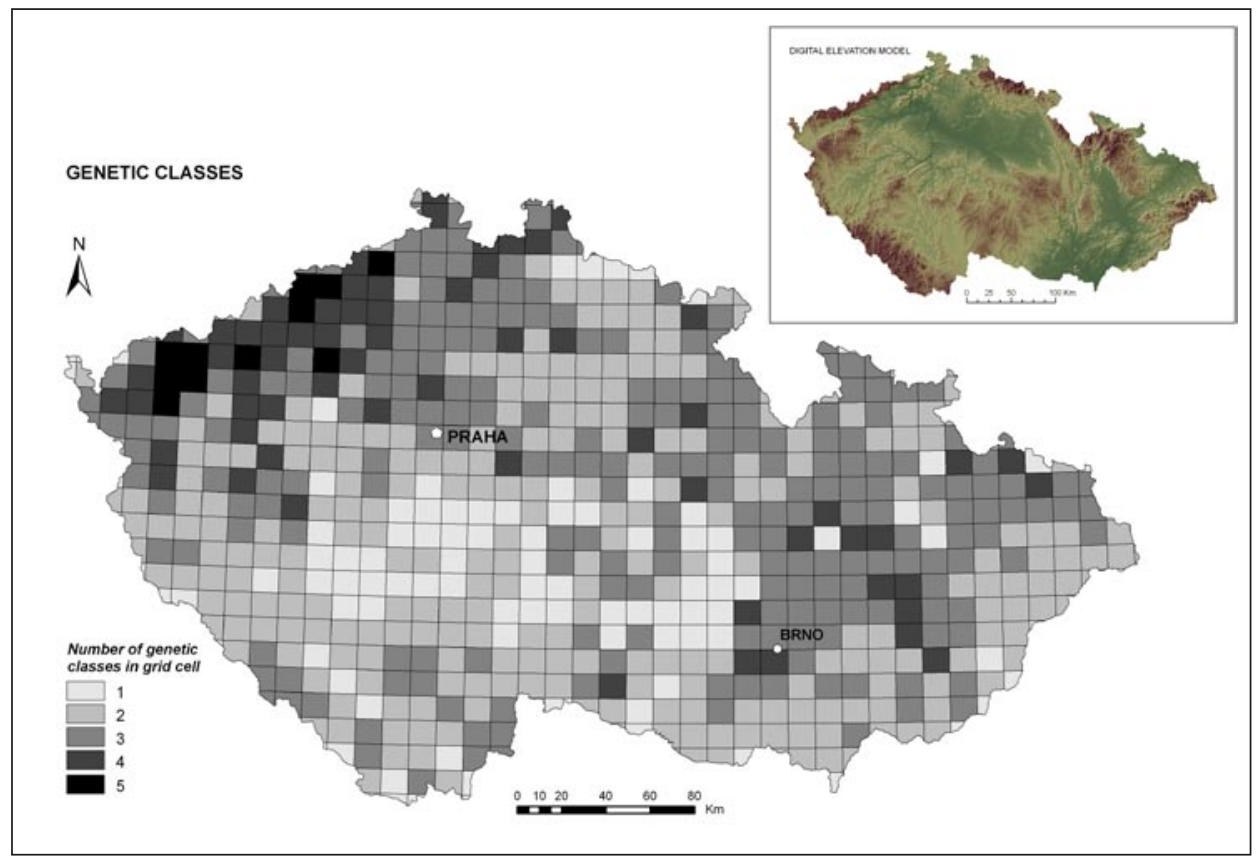

Fig. 5 - Number of landform genetic classes (total geomorphodiversity - NGC) on the territory of Czechia 
DIKAU, R. (1992): Aspects of constructing a digital geomorphological base map. Geologisches Jahrbuch, A122, pp. 357-370.

EIDEN, G., KAYADJANIAN, M., VIDAL, C. (2010): Capturing landscape structures: Tools. From land cover to Landscape Diversity. Ec.europa.en/agriculture/publi/landschape/ch1. htm.

GUSTAVSSON, M., SEIJMONSBERGEN, H., KOLSTRUP, E. (2008): Structure and contents of a new geomorphological GIS database linked to a geomorphological map - with an example from Liden, central Sweden. Geomorphology, 95, No. 3-4, pp. 335-34.

HENGL, T., HANNES, I. eds. (2009): Geomorphometry. Concepts, Software, Applications. Developments in Soil Sciences, 33, pp. 1.

HJORT, J., LUOTO, M. (2010): Geodiversity of high-latitude landscapes in Northern Finnland. Geomorphology, 115, pp. 109-116.

HRNČIAROVÁ, T., MACKOVČIN, P., ZVARA, I. et al. (2009): Landscape Atlas of the Czech Republic. Ministry of Environment of the Czech Republic and The Silva Tarouca Research Institute for Landscape and Ornamental Gardening, Praha, 332 pp.

KERTESZ, A., MARKUS, B., (1992): GIS applications in geomorphology and in geomorphological mapping. Geologisches Jahrbuch, A 122, pp. 381-387.

LÉTAL, A., VOŽENÍLEK, V. (2002): Legenda podrobných geomorfologických map (digitální formát). In: Kirchner, K., Roštínský, P. (eds.): Geomorfologický sborník 1. Stav geomorfologických výzkumů v roce 2002. Př́íspěvky z mezinárodního semináře konaného 10.-11. 6. 2002 v Brně. PřF MU v Brně, ČAG, Brno, pp. 86-89.

LOŽEK, V. (2006): Biodiverzita a geodiverzita. Ochrana př́rody, 60, No. 7, pp. 195-199.

MINÁR, J., EVANS, I. S. (2008): Elementary forms for land surface segmentation: the theoretical basis of terrain analysis and geomorphological mapping. Geomorphology 95, pp. 236-259.

PANIZZA, M. (2009a): The Geomorphodiversity of the Dolomites (Italy): A Key of Geoheritage Assessment. Geoheritage, 1, pp. 33-42.

PANIZZA, M. (2009b): Geomorphodiversity of the Dolomites and some remarks on recent rock falls. In: Malet, J-P., Remaitre, A., Bogaard, T. (eds.) Proceedings of the Landslide Processes Conference Université de Strasbourg, 6, 7/2/09, pp. 343-345.

SERRANO, E., RUIZ-FLANO, P. (2007): Geodiversity: a theoretical and applied concept. Geographica Helvetica, 62, No. 3, pp. 140-145.

Smolová, I. (2008): Těžba nerostných surovin na území ČR a její geografické aspekty. Univerzita Palackého, Olomouc, $195 \mathrm{pp}$.

STEHLÍK, O. (1965): General Geomorphological Map of West Part of ČSSR 1:500,000. In: Demek, J. et al.: Geomorfologie Českých zemí. Nakladatelství Československé akademie věd, Praha, 335 pp. and map

VITEK, J.D., GIARDINO, J.R., FITZGERALD, J.W. (1996): Mapping geomorphology: A journey from paper maps, through computer mapping to GIS and Virtual Reality. Geomorphology, 16, No. 3, pp. 233-249.

VOŽENÍLEK V. et al. (2001): Integrace GPS/GIS v geomorfologickém výzkumu. Vyd. UP Olomouc, $185 \mathrm{pp}$.

\section{Shrnutí}

\section{GEORELIÉF ČESKA A JEHO KVANTITATIVNÍ HODNOCENÍ V PROSTŘEDÍ GIS}

V posledních letech aplikace technologií GIS poskytla geomorfologům řadu nových možností pro kvantitativní hodnocení georeliéfu a zpracování geomorfologických databází (Minár, Evans 2008).

Autoři v rámci prací na novém Atlasu krajiny České republiky (Hrnčiarová, Mackovčin, Zvara et al. 2009) zpracovali v letech 2007-2009 novou obecnou geomorfologickou mapu Česka v prostředí GIS (Demek, Balatka, Kirchner, Mackovčin, Pánek, Slavík 2009). Tvorba mapy probíhala $\mathrm{v}$ měřítku 1:200 $000 \mathrm{~s}$ výslednou atlasovou mapou v měřítku 1:500 000 . Legenda geomorfologické mapy byla sestavena podle zásad Komise pro geomorfologické mapování Mezinárodní geografické unie (IGU), uvedených v projektu Jednotného klíče k po- 
drobným geomorfologickým mapám světa (Bashenina et al. 1968; Demek, ed. 1972; Demek, Embleton, Kugler, eds. 1982). Základní mapovací jednotkou byly tvary georeliéfu. Povrchové tvary jsou v mapě vyjádřeny ve třech vrstvách, a to plošné, lineární a bodové. Pro vyjádření geneze tvarů byly v mapě použity barvy. Při konečném zpracování výsledné mapy bylo potřeba přistoupit k určité generalizaci obsahu podle plošného rozsahu a významu (např. suků), což se přirozeně projevilo i v kvantitativních údajích.

Digitální mapa poskytla možnost kvantitativního hodnocení georeliéfu Česka a geomorfodiverzity státního území. Podle mapy jsou na území republiky v georeliéfu nejvíce zastoupené fluviální erozně-denudační svahy, které zabírají plochu $48051,8 \mathrm{~km}^{2}$ (tj. 63,62 \% území státu). V mapě jsou tyto erozně denudační svahy rozdělené podle sklonu. Mírně skloněné svahy o sklonu $2-5^{\circ}$ (celkem 500 ploch) zabírají $18309,6 \mathrm{~km}^{2}$ (tj. 23,08 \% území státu). Největší rozšíření mají středně skloněné svahy o sklonu $5-15^{\circ}$ (972 ploch), které celkově zabírají plochu $20473,6 \mathrm{~km}^{2}$ (tj. 25,82 \% rozlohy státu). Svahy se sklonem větším než $15^{\circ}$ (981 ploch) zabírají $9268,6 \mathrm{~km}^{2}$ (tj. 11,72\% rozlohy státu).

Vedle erozně-denudačních svahů se v georeliéfu Česka vyskytují i strukturní svahy vázané na výchozy odolných hornin. V mapě je uvedeno 241 lokalit strukturních svahů o celkové délce $632,3 \mathrm{~km}$, které dohromady zabírají v polygonové vrstvě plochu $312,8 \mathrm{~km}^{2}(1,67 \%$ rozlohy státu).

Erozně-denudační plochy o sklonu $0-2^{\circ}$ se na území státu vyskytují jednak jako polygenetické zarovnané povrchy a jednak jako strukturně-denudační plošiny. Z vrcholových polygenetických zarovnaných (sečných) povrchů jsou to především plošiny holoroviny v České vysočině a moravsko-slezském teránu. Autoři v mapě vymezili 1056 plošin o rozloze větší než 30 hektarů (největší plošina zabírá plochu 130,3 km²), které celkově mají plochu 3076,2 km² (tj. 3,88 \% povrchu státu). V karpatské části republiky se vrcholové sečné povrchy nacházejí v Javorníkách, kde 6 plošin větších než 30 hektarů zabírá plochu $4,7 \mathrm{~km}^{2}$. V mapě je poprvé vyznačené rozšíření úpatních povrchů na celém území Česka, a to jak skalních pedimentů, tak i erozních glacisů. V mapě je znázorněných 483 pedimentů zabírajících plochu $1859,7 \mathrm{~km}^{2}$ (2,36 \% plochy státu). Místy se skalní pedimenty vyskytují ve dvou stupních na sebou a spojují se v pediplény. Časté jsou údolní pedimenty. Méně rozšířené erozní glacisy se vyvinuly v méně odolných horninách při úpatí svahů tvořených odolnějšími horninami. V mapě je uvedeno 43 lokalit erozních glacisů.

Na mírně ukloněných vrstvách skalního podloží se nacházejí strukturně denudační hřbety, které zabírají plochu 1317,3 km² (1,67 \% státního území) a mají v polygonové a lineární vrstvě délku 1184,6 km. U 103 lokalit nesouměrných hřbetů (kuest) zabírají příkré čelní erozní svahy plochu $72,2 \mathrm{~km}^{2}(0,09 \%)$ a mají v polygonové a lineární vrstvě délku $376,9 \mathrm{~km}$. Mírné týlové svahy kuest zabírají plochu $588,4 \mathrm{~km}^{2}(0,09 \%$ státního území). V mapě se rovněž nachází 43 erozních glacisů zabírajících plochu $415,2 \mathrm{~km}^{2}(0,53 \%$ plochy státu). Čtvrtohorního stáří jsou kryopedimenty, které se vyvíjely v chladných obdobích pleistocénu v přítomnosti permafrostu. V mapě se nachází 121 kryopedimentů většího rozsahu, které zabírají plochu $2071,0 \mathrm{~km}^{2}$ (2,63\% povrchu státu).

Z pseudokrasových erozně-denudačních tvarů zabírají největší plochu pseudokrasová skalní města, a to 16 skalních měst v polygonové vrstvě (plocha $302,7 \mathrm{~km}^{2}, 0,38 \%$ území státu) a 21 lokalit v bodové vrstvě.

$\mathrm{Z}$ akumulačních tvarů georeliéfu Česka zaujímají největší plochy povrchy na spraších, zejména ve sníženinách (celkem $6370,3 \mathrm{~km}^{2}, 8,04 \%$ státního území). Tyto povrchy, na kterých se většinou vyvinuly úrodné půdy mají velký hospodářský význam. Následují rovinné povrchy údolních a poříčních niv, které zabírají plochu 3791,0 km², 4,79 \% státního území). Značné plochy rovněž zabírají povrchy akumulačních říčních teras (tab. 1), a to $2688,5 \mathrm{~km}^{2}$ (3,41 \% státního území). Z fluviálních tvarů jsou to dále proluviální roviny $\left(340,0 \mathrm{~km}^{2}\right.$, $0,43 \%$ státního území) a proluviální náplavové kužely $\left(181,7 \mathrm{~km}^{2}, 0,23 \%\right.$ státního území. V oblastech kam zasáhl v pleistocénu pevninský ledovec zabírají největší plochy sandry (51 lokalit, plocha 469,7 km², 0,60\% státního území). Z eolických tvarù se v mapě vyskytuje ještě 138 přesypů zabírajících v polygonové vrstvě plochu $10,7 \mathrm{~km}^{2}(0,01 \%$ státního území).

Neotektonické tvary na území republiky se dělí do dvou skupin, a to na kerné a vrásové. Z kerných tvarů bylo na území republiky identifikováno 541 zlomových svahů různé výšky i výraznosti. Z toho je v mapě 461 zlomových svahů vyznačeno plošně a celkově zabírají plochu 907,3 km² (1,15 \% státního území). Dalších 80 zlomových svahů je vyznačeno lineárními značkami. Celkově délka zlomových svahů činí $2501,3 \mathrm{~km}$. Z vrásových tvarů jsou v plošné 
vrstvě 3 lokality svahů antiklinál, zabírajících plochu 90,4 km² $(0,11 \%)$ a 1 svah synklinály zabírající $30,1 \mathrm{~km}^{2}$ (0,04 \% státního území). V lineární vrstvě jsou vyznačeny osy 21 megaantiklinál (celková délka 378,8 km) a osy 7 megasynklinál (celková délka 342,0 km). Do neovulkanických tvarů tradičně řadíme tvary, které vznikly sopečnou činností v třetihorách a čtvrtohorách. Ve skutečnosti se však vzhledem k rozsáhlému odnosu neovulkanických tvarů většinou jedná o erozně-denudační a exhumované tvary. I přesto tyto tvary jsou důležité z hlediska geomorfodiversity krajiny. V mapě autoři rozlišili 219 neovulkanických kup a kuželů zabírajících plochu 102,0 km² (0,13 \% státního území). U vypreparovaných subvulkanických těles byla provedena generalizace podle plošné rozlohy (tvary větší než 12 ha).

Autoři měli problémy s mapováním antropogenních tvarů, které se neustále mění. Využili při mapování digitální databázi České geologické služby a aktuální letecké snímky. Vedle kvantitativního hodnocení jednotlivých tvarů a skupin tvarů georeliéfu autoři přistoupili s pomocí plošné vrstvy zmíněné mapy ke kvantitativnímu hodnocení prostorových struktur georeliéfu v prostředí GIS (viz obr. 3, 4 a 5). Práce na geomorfologických mapách pro Atlas krajiny ČR ukázaly, že GIS je důležitým prostředkem geomorfologického výzkumu.

Práce vrcholí hodnocením geomorfodiversity státního území.

Obr. 1 - Výřez z digitální geomorfologické mapy Česka (Demek, Balatka, Kirchner, Mackovčin, Pánek, Slavík 2009)

Obr. 2 - Legenda digitální geomorfologické mapy Česka (Demek, Balatka, Kirchner, Mackovčin, Pánek, Slavík 2009)

Obr. 3 -Rozmístění tříd tvarů georeliéfu na území Česka

Obr. 4 - Hustota tvarů georeliéfu na území Česka

Obr. 5 - Počet genetických tř́íd tvarů georeliéfu (celková geomorfodiverzita) na území Česka

Authors' affiliations: J. Demek, P. Mackověin and P. Slavík are affiliated with The Silva Tarouca Research Institute for Landscape and Ornamental Gardening, public research institute, Průhonice, Dept. of Landscape Ecology and Dept. of GIS Applications, Lidická 25-27, 60200 Brno,Czechia; e-mail:demekj@seznam.cz, petr.mackovcin@vukoz.cz, petr.slavik@vukoz.cz. B. Balatka: Oldřichova 12, Praha 2, Czechia. K. Kirchner is affiliated with Institute of Geonics Academy of Sciences of the Czech Republic, Ostrava, public research institute, Branch Brno, Drobného 29, Brno, 602 00, Czechia, e-mail: kirchner@geonika.cz. T. Pánek is affiliated with University of Ostrava, Faculty of Science, Department of Physical Geography and Geoecology, Czechia, e-mail: tomas.panek@osu.cz.

Initial submission, 16 March 2010; final acceptance, 11 January 2011.

Please cite this article as:

DEMEK, J., BALATKA, B., KIRCHNER, K., MACKOVČIN, P., PÁNEK, T., SLAVÍK, P. (2011): Relief of Czechia: quantitative evaluation in the GIS environment. Geografie, 116, No. 2, pp. 111-129. 